\title{
Uncanny Parallels: Jennifer Kent's The Nightingale, Violence, and the Vandemonian Past
}

\begin{abstract}
Set in mid-1820s Van Diemen's Land, The Nightingale depicts a dark and disturbing Tasmanian past populated with redcoats, convicts, Aboriginal people, and a few free settlers. Controversial scenes include the repeated rape of a young female convict, the murders of her husband and infant, and the rape and murder of an Aboriginal woman. Uncanny parallels can be drawn between the on-screen experiences of the white female lead, and the violence visited on the bodies of Tasmanian colonial woman Elizabeth Tibbs, her husband, and infant in 1826. After situating the film within its historical context, this paper provides a mimetic reading through elaborating these parallels. It interrogates key points of divergence between these fictional and historical accounts of women's lives to explore what they reveal about gender, class, race, violence, and justice in colonial Van Diemen's Land and its depiction in twenty-first century Australia.
\end{abstract}

\section{Introduction}

When the film The Nightingale (Dir. Jennifer Kent, 2019) screened at the Ritz Cinema in Randwick during the Sydney Film Festival in June 2019 its reception by the audience excited some controversy. Set in mid-1820s Van Diemen's Land (now Tasmania) where the British invaders and the original inhabitants of the land were on the brink of a genocidal colonial war, this award-winning Australian period drama graphically depicts violence perpetrated by British regimental soldiers against the colony's convict servants and the island's Aboriginal people. During the opening scenes of The Nightingale, Irish convict Clare Carroll (Aisling Franciosi) is raped by Lieutenant Hawkins (Sam Claflin), to whom she had been assigned as servant, and then gang raped by Hawkins and his underling, Ruse (Damon Herriman). At the film's first screening at the Ritz Cinema, a woman walked out while loudly proclaiming 'I'm not watching this. She's already been raped twice'. The film was screened again the following day, with approximately fifty people walking out during the course of these two screenings in response to the violence depicted (Thomas 2019). As this article aims to demonstrate, though, rather than being excessive, the on-screen violence reflects the lived realities of the Vandemonian frontier.

As Robert Rosenstone $(2018,33)$ has elaborated, film functions differently from the more traditional written histories in that it brings aspects of the past to life through adding 'movement, colour, sound, and drama to the past'. Viewing a historical drama immerses audiences viscerally in the lived experiences of historic actors as imagined and interpreted through a visual medium. Intense emotions may be excited, and reactions provoked. In relation to history and film, Marnie Hughes-Warrington $(2007,103)$ has explored Jean 
Baudrillard's notion of hyperreality, positing that film goes beyond the real to the hyperreal, aiming for perfection in its representation of reality.

Audience responses to The Nightingale beg the question as to whether viewers found cinematic representations of the Vandemonian past too real? Was the level of violence against the person depicted in the film warranted? This article offers a mimetic reading of The Nightingale, comparing key violent episodes depicted in the film with known historical events to demonstrate the extent to which this on-screen violence has its foundation in historical fact and was therefore, in my view, justified. After situating The Nightingale in pertinent cinematic and historical contexts, I draw on a specific historical case with uncanny parallels to Kent's film. Ultimately, I argue that the ways in which the Vandemonian past is represented in The Nightingale are historically accurate and even, in parts, were less graphically violent than some incidents recorded as actually having taken place in Tasmanian history. It is worth noting that this argument is consistent with the director's assertion that 'Tasmanian Aboriginal elders ... feel it's [the film is] an honest and necessary depiction of their history' (Thomas, 2019). It was a story that they wanted to be told.

\section{Situating The Nightingale}

One of the defining characteristics of the opening decades of twenty-first century Australian cinema has been the release of a number of feature films depicting the nation's violent colonial past and its aftermath. Describing such films as 'an experiment in historical allegory', Felicity Collins $(2008,56)$ identified several significant exemplars sharing historical-allegorical features, including One Night the Moon (Dir. Rachel Perkins, 2001), Rabbit-Proof Fence (Dir. Phillip Noyce, 2002), Black and White (Dir. Craig Lahiff, 2002) and The Tracker (Dir. Rolf de Heer, 2002), The Proposition (Dir. John Hillcoat) and even the 'precolonial' film, Ten Canoes (Dir. Rolf de Heer, 2006). I posit that The Nightingale can usefully be situated in this cycle of Australian history films, particularly given its close conformity to a description originally bestowed by Collins $(2008,64)$ on The Proposition in that it, too, is a 'frontier saga of retributive violence'.

With its setting in the Vandemonian bush and towering mountains of the interior, and in the nascent town of Launceston in the north of the island with its surrounding farmlands, The Nightingale depicts a colony transitioning violently from Aboriginal custodianship to white commerce and cultivation. Visible hierarchies of class, race, and gender populate the setting embodied in the persons of the soldiery, convicts, free settlers, and Aboriginal people. The uniformed redcoats are clothed in accordance with both their occupation and their 
seniority. Rank matters. This is evident in the ways in which the officers brutalise their underlings. Yet redcoats of different ranks band together to perpetrate violence against convicts and Aboriginal people alike. Gender comes into sharp focus particularly in the several rape scenes involving soldiers and, initially, a convict woman and, later, an Aboriginal woman. The men take what they desire from the women, urging their male companions to do likewise, their violent incursions into these female bodies cementing the bonds between the perpetrators. So brutally used, the women are discarded and left for dead with the males of their own classes and races seemingly unable to defend them against their attackers. Like its recent cinematic predecessors mentioned above, The Nightingale inscribes new patterns of subjectivity on the colonial landscape.

Collins $(2008,56)$ has explained how, while showing a rich cinematic reflection upon Australia's troubled past, films depicting Australia's violent colonial past mainly speak to present day understandings. She elaborates how these films, while 'conventional in form', are also 'experimental in the sense identified by Meaghan Morris: they "help create the possibility of a 'field' of intersubjectivity where a different form of public memory may take shape", a possibility that she suggests some Australian historians find discomforting. This, then, begs the question as to how The Nightingale might influence public memory of the Vandemonian frontier, especially given Tasmania's prominence in public debates about Australian history a generation ago as the so-called history wars raged. It is my contention that Kent's film has the capacity to engage its audience in deep, nuanced understanding of Australia's fraught past. This depends not only on viewers bearing witness to the violence and racism in the film, but also by accepting that the film's violence and racism is historically accurate and not merely theatrically gratuitous (Thomas 2019).

This is perhaps most strikingly achieved through the central narrative roles given to soldiers. One of the most significant contributions Kent makes is to reinscribe British regimental soldiers, or redcoats, back into the Vandemonian frontier. Despite their overwhelming presence in the early colony in roles ranging from guards on convict transports (ships) to local police magistrates, Van Diemen's Land has often been presented as the site of a settler and Aboriginal encounter with the redcoats relegated to minor roles. In James Boyce's (2008) internationally-acclaimed Van Diemen's Land, for example, the main protagonists were convicts who, sometimes as bushrangers, adapted to a kangaroo economy and founded a new way of life. British redcoats are curiously absent, while Aboriginal people are largely relegated to a substantial appendix. Soldiers occupied the background in military historian John Connor's (2002, 84-101) analysis of the frontier war that began in Van 
Diemen's Land in the mid-1820s. Citing earlier works by Henry Reynolds and Lyndall Ryan, Connor focussed on the respective casualty rates of settlers and Aboriginal people before going on to analyse the military strategies employed by settlers and Aboriginal people respectively. His analysis of the 'Black Line' operation as a military strategy also foregrounds settlers and convicts with the field police and military remaining shadowy figures.

In a significant departure from earlier works, Nick Brodie (2017) recently demonstrated in his revisionist history The Vandemonian War: The Secret History of Britain's Tasmanian Invasion, a monograph constructed from thousands of previously overlooked historical records, Van Diemen's Land under Lieutenant-Governor George Arthur (the era in which The Nightingale is set) was essentially a military state. The full extent of the violence perpetrated by Arthur's elite military regiments and parties of para-military field police and settler mercenaries, who were often accompanied by redcoats, is yet to be fully appreciated by present-day Australians.

Moreover, Brodie (2017, 5-21) points out that as well as being the island colony's highest-ranking civil authority, the Lieutenant-Governor, Colonel Arthur was also the highest-ranking military official, the colonel commanding. Shortly after he arrived in Hobart, he engaged in strategies designed to fortify the burgeoning British colony against armed resistance from its original inhabitants. Arthur ordered more weapons from London, advanced projects to grant land to military settlers, formed an armed field police force drawn from convict ranks, directed the establishment of military stations at crucial frontier waypoints to partition off designated 'settled districts', and so on. The colony's civil administration was governed from Hobart through regional police magistrates, the majority of whom were serving military officers or former soldiers. Once preparations were complete, Arthur directed a series of offensives against Aboriginal people across the breadth and length of Van Diemen's Land.

Ultimately, Arthur issued settlers and convicts alike with hundreds of guns and thousands of rounds of ammunition. Convicts who fought against Aboriginal people were rewarded. Arthur utilised capture parties, initially against bushrangers and later against Aboriginal people, comprising soldiers, paramilitary men, convicts, and volunteers, often with Aboriginal auxiliaries assigned as guides. ${ }^{1}$ Arthur's Vandemonian war eventually included the largest ground offensive in Australian colonial history. In short, as Brodie demonstrates exhaustively, throughout the period in which The Nightingale is set the colony 
was at war, with distinctions between civil and military authority or responsibility often blurred.

During Arthur's regime military and civilian parties scoured the island for Aboriginal people, taking some prisoner and injuring or killing others. They destroyed Aboriginal campsites and caches of weapons. Arthur knew his war parties were killing their opponents, but he continued to send them out regardless. He feigned ignorance after John Batman, leader of one of the parties and later 'founding father of Melbourne', fatally shot two injured Aboriginal prisoners in his custody. His strategies became more severe over time. Reward schemes, like bounties of $£ 5$ for an adult Aboriginal person and $£ 2$ per child, were nominally designed to encourage colonists to bring in live captives, but in at least one demonstrable case was later extended to cover not only the living but also the dead (Brodie 2017, 229). At the same time, Arthur's regime leaked stories to the press to manage the public's (and posterity's) understanding of the war.

As the Vandemonian war progressed, Arthur ordered men to conduct many covert operations. While there were some public expressions of empathy for Aboriginal people, Aboriginal people were usually represented as aggressors, thereby justifying government action and even secrecy.

In the latter stages of the war, between 1829 and 1834, Arthur sent a conciliator, George Augustus Robinson, to carry out so-called diplomatic "friendly missions" to Aboriginal people. While these missions were taking place, Arthur continued to orchestrate military and paramilitary operations, including some conducted by nominally diplomatic operatives. Eventually, Arthur declared that details of the war had to become a military secret. He then continued with a series of major military offensives against the island's remaining Aboriginal population. While the redcoats in The Nightingale are not seen to be engaging in all the actions recorded as having taken place in Van Diemen's Land, their strong presence in the film reintroduces British regiments as key players in the colony in the 1820s. The uncouth behaviour of those located in the interior of the island punctuated with episodes of extreme violence hints at the wider role these men played in pacifying the colony.

\section{Vignettes of Violence}

Australian cinema goers are no strangers to on-screen violence, particularly violence enacted on the bodies and psyches of women. In The Proposition, for example, Tanya Dalziell (2009, 122) has described how 'the violation of women's bodies ... are called upon as both the motivation and means of resolving the proposition propelling the film'. In a similar way, Lieutenant Hawkins' repeated violations of convict servant Clare Carroll which result in the 
deaths of her immediate family propel the narrative in The Nightingale forward as Clare follows Hawkins to exact revenge. A significant point of departure, though, is the extent to which these violations are being engaged with critically. As Dalzeill $(2009,122)$ pointed out, very little was said about the sexual violence perpetrated against women in critical reviews of The Proposition. However, a decade later, the sexual violence depicted in The Nightingale became instantly controversial. This begs the question as to what has shifted in the zeitgeist in the intervening years?

The late twenty-teens have seen an increasingly widespread, strong focus on calling out and preventing sexual harassment and assault with a particular focus on alleged perpetrators in positions of power who formerly seemed, by dint of their exalted positions, to be immune from prosecution. The rise of social media has empowered social justice movements as evidenced by the way in which the 'me too' hashtag went viral from 24 October 2017 in response to actress Alyssa Milano's encouragement to use \#MeToo as a way to indicate that they had been sexually harassed or assaulted. Millions of people responded (Mendes, Ringrose and Keller 2018, 236). In a social climate in which rape and redress are highly topical, and in which such debates are readily accessible to, if not fuelled by, the wider public, it is unsurprising that graphic scenes depicting rapes in The Nightingale instantaneously generated heightened public and critical attention.

As outlined above, early in the film Clare is raped by the military officer to whom she has been assigned, seemingly in retaliation for her having inquired about an overdue letter of recommendation from him which would facilitate her freedom. When Clare's husband Aidan (Michael Sheasby) intervenes on her behalf, a fight breaks out following which Aidan and Clare make hurried preparations to flee. But as Clare pauses to feed their hungry baby, Hawkins arrives at their small bush home with Ruse and Private Jago (Harry Greenwood). The aggrieved Hawkins taunts Aidan about the numerous times he has had sexual intercourse with Clare then proceeds to rape her in front of her husband before urging Ruse to take his turn with the helpless woman. Hawkins then shoots dead the protesting Aidan, while a rattled Jago is ordered to make the hungry, distressed baby shut up, leading to the private dashing the baby's brains out against a wall. Clare is then struck forcefully, albeit not fatally. The soldiers depart, leaving the Carroll family for dead. Clare survives and sets out on a journey 
to seek revenge against Hawkins who she learns has departed on foot for Launceston to seek a promotion.

The vulnerability of women in Van Diemen's Land to violence and oppression has long been recognised by scholars. In relation to the island colony's convict population, for example, Kay Daniels (1998) delineated how transportation resulted in different opportunities becoming available to male convicts from female convicts. While men's labour was valued and rewarded, women were seen as potential sexual partners rather than as workers. This led to their being coerced into illicit and sometimes forced sexual relationships as well as being 'consigned to domestic patriarchy', an experience Daniels $(1998, i x)$ described as 'hidden, unregulated, [and] often brutal'. She outlined how convict women needed to have a 'protector', something that their male counterparts would not have found necessary.

In The Nightingale, Clare's protector is somewhat unconventional. Following the murders of her husband and infant, she is accompanied by Aboriginal man Billy/Mangana (Baykali Ganambarr) as they track Hawkins and his various companions who are en route to the northern settlement of Launceston. Hawkins' entourage's movements through the bush are punctuated by episodes of graphic violence. While viewing The Nightingale in a cinema with surround sound led to my averting my eyes and covering my ears as parts of certain scenes unfolded, I can nevertheless attest to the historical veracity of the troubling violence. For example, when Ruse encounters an Aboriginal woman, Lowanna (Magnolia Maymuru) and her small child in the bush, he kidnaps and restrains the woman and then rapes her. When an armed altercation takes place between Hawkins' and Ruse's party and a group of Aboriginal men, including Lowanna's husband (Dallas Mugarra), who are intent on rescuing her, Hawkins shoots Lowanna.

White men raping or killing Aboriginal women with impunity demonstrably occurred in Van Diemen's Land. An illuminating example is the 'Goldie incident' that took place on 21 August 1829 in the north-west of the colony, an area dominated by the Van Diemen's Land Company with its extensive land holdings. On the day in question, Company employee Alexander Goldie was overseeing the erection of sheep sheds at Cooee Point when his workers noticed two Aboriginal women and a child. As they tried to trap the women on the beach, one fled into the scrub only to be chased by Goldie who was on horseback. During his absence, the remaining men shot and wounded the other Aboriginal woman, then killed her with an axe. The woman captured by Goldie was subsequently kept in irons and made to perform domestic labour for the Van Diemen's Land Company employees (Johnson and McFarlane 2015, 184). 
In the aftermath of the Goldie incident, the manager of the Van Diemen's Land Company Edward Curr was instructed by Arthur to hold a formal inquiry. As historians Murray Johnson and Ian McFarlane $(2015,183)$ have explained, the Van Diemen's Land Company functioned as 'a state within a state, and with his magisterial powers Edward Curr possessed absolute authority'. Curr conveniently became 'ill' following the Goldie incident, but came under continual pressure from Arthur to carry out an investigation. His inquiry into the woman's death finally took place four months after the Goldie incident. While riding out into the field purportedly to conduct interviews, Curr led a contingent of armed Compnay men against local Aboriginal people, promising his men spirits 'if they could bring back an Aboriginal head so that it could be mounted on the roof of a stock hut to serve as a grisly warning', his behaviour being read as a bid to reinspire confidence in his leadership. He justified his actions on the grounds that he was simply protecting the Company's interests. Unsurprisingly, Curr's magisterial inquiry resulted in him finding that the death of the unnamed Aboriginal woman could not be considered murder. His tenuous reasoning was based on Arthur having declared martial law in the settled districts of Van Diemen's Land in November 1828 (Johnson and McFarlane 2015, 183-189). When Arthur sought advice from his solicitor general Alfred Stephens, a man whom I have described elsewhere as 'the hanging judge' in relation to Aboriginal defendants, Stephens prevaricated (Harman 2012, 88-100). Despite the Van Diemen's Land Company not falling within the settled districts, and martial law therefore not having applied across its territories, nobody was ever held accountable for the murder of the Aboriginal woman at the centre of the Goldie incident, nor for the murders of many other Aboriginal people on Van Diemen's Land Company land grants (Johnson and McFarlane 2015, 183-189).

While comparatively well known, the Goldie incident was by no means an isolated episode of colonial violence against Aboriginal women. In the late 1820s and early 1830s, John Batman was one of numerous men who headed up capture parties in Van Diemen's Land. Batman supplemented his roving party with Aboriginal men recruited from New South Wales who became known as the 'Sydney natives' despite none of them being from Sydney. One of Batman's strategies in deploying the men was to supplement their ranks with a group of Tasmanian Aboriginal women who he thought could act as emissaries to encourage their compatriots to surrender. In April 1830, Batman secured the release from Launceston gaol of four women he had captured the previous September so that they could accompany Pigeon and Crook, two of the mainlanders, into the bush. Of particular resonance in the context of episodes depicted in The Nightingale are the steps that Batman had to take to ensure the 
women's lives would not be at risk by being in the bush. He provided them with brass plates to hang around their necks as symbols of their status as emissaries, intending thereby to ensure that they would not simply be shot on sight. Batman also asked that another of the roving parties in the district, led by convict John Danvers, be instructed not to shoot any Aboriginal people while Batman's mission was taking place (Harman 2009, 16). These extraordinary measures underline the reality of Aboriginal people's vulnerability to unmitigated colonial violence in Van Diemen's Land during the times depicted in The Nightingale, a vulnerability portrayed cinematically not only through the rape and murder of Lowanna but also in a scene in which colonists killed a group of Aboriginal prisoners whom they had chained by the neck before severing the head of one of the deceased. ${ }^{2}$

Violence and a sort of lawful-lawlessness thus characterised the Vandemonian frontier in the 1820 s and into the early 1830s. The violent episodes depicted in The Nightingale thus have historical veracity, in a general sense. But there are also some strikingly specific parallels as well. I now turn to a historical case study with uncanny equivalences to the film's episodes and key narrative moments, which furthers the plausible historicity of this film.

\section{Manuscript 3251}

Living in Tasmania, The Nightingale resonates in such a way that debriefing with friends after watching it seems almost mandatory. Shortly after Colette McAlpine saw the film, we sat down to share our thoughts. I was intrigued by her observation that Clare's story was similar to that of Elizabeth Tibbs, a free woman who was the daughter of one Colette's convict ancestors Ann Carey, per Neptune, a woman whose military husband is said to have walked overland from Hobart to Launceston. By the mid-1820s, Ann's daughter Elizabeth had married and was living on a farm with her husband and infant in northern Van Diemen's Land. Colette generously shared her relative's story with me, together with a pertinent archival manuscript, and gave her consent to my drawing on it in this article. Kent drew on archival sources and oral histories in scripting The Nightingale but has not commented publicly on whether her script was influenced by the Tibbs case.

The historical events that I am about to recount take place late in 1825 and in the early months of 1826, precisely the time in which The Nightingale is set. Rather than featuring redcoats, though, our main protagonists are a group of bushrangers. Their story survives today in several archival documents, perhaps the most remarkable of which is a voluntary statement provided by one of the men, John Perry, taken while he was being held in His 
Majesty's Gaol at Launceston awaiting trial for his part in the events described (Manuscript 3251 1826, National Library of Australia).

Perry described how he, along with several other men, broke out of the watch house in Launceston on a Sunday night two or three weeks before Christmas 1825. One of the men, Thomas Jeffries, became the bushrangers' leader. Jeffries called himself 'Captain' while on the run and dressed flamboyantly 'in a long black coat, red waistcoat, and a kangaroo skin cap' (Hobart Town Gazette 29 April 1826, 2). At least, that is how he was attired when, on New Year's Eve 1825, he, Perry, and Edward Russell arrived uninvited at John and Elizbeth Tibbs' farm about five miles from Launceston. The gang robbed the hut, then kidnapped Tibbs, his wife and baby, and their convict servant. After forcing their captives to walk around two miles from their farm, the captors tied them up. Tibbs and his servant were ordered to kneel and say their prayers, following which both men were shot. Jeffries and Russell then took the Tibbs' five-month-old baby away and murdered it. A search party later retrieved the infant's mutilated remains from the bush. Local wildlife had fed on an arm and both legs (Colonial Times and Tasmanian Advertiser 13 January 1826, 4). After the murder of her child, Elizbeth Tibbs was gang-raped before being set free. She returned to the family farm in a deeply distressed state the afternoon following her abduction.

A little over a week after their attack on the Tibbs family, Jeffries, Russell and Perry were travelling across the coast at the top of the island where Perry later said they met four men and an Aboriginal woman. He provided a rich description of the group from which it seems that the men were probably sealers:

all the men had Guns, two of them had pea jackets, checked shirts and red caps, the two other men had red shirts and sealskins caps, all four of them had canvas trowsers, one of them who had a pea jacket was a thin middle sized old man, he had a red comforter round his neck and carried his ammunition in a kangaroo skin pouch fastened round him with a leather belt, the other man in a pea jacket was about twenty three years of age, light hair and fair complexion, he had a pouch similar to the others - the men in red shirts were about five feet ten inches high, stout made and dark complexion, one of them had a red comforter, the other a black comforter with a green stripe, they appeared about thirty years old and resembled each other very much, I saw them when I was at Preservation Island they belonged to a Sydney boat (Manuscript 3251 1826, National Library of Australia).

According to Perry, the bushrangers shot the men, then 'took the black woman to a Lagoon about a quarter of a mile off, where all three of us had connexion with her, Jeffries first, then 
I and afterwards Russell, we then all four dined together off some fat cakes and kangaroo steamer, neither of us had any further connexion with the woman; about three of four o clock in the afternoon Jeffries said the Blacks were all treacherous that he had been taken by them at Sydney, and shot her through the head with a pistol' (Manuscript 3251 1826, National Library of Australia).

Some days after shooting the sealers, then raping and murdering an unnamed Aboriginal woman, the bushrangers were exhausted and hungry. According to Perry:

Jeffries said to me and Russell, if you like the first man that falls asleep shall be shot, and become food for the other two, Russell and I said "we board it" / were glad of it/ two days after we were going up a rocky and scrubby high hill, when we all sat down to rest ourselves, about eleven o clock in the day, Russell fell asleep, I was sitting close to him, I took a pistol from my knapsack which was loaded with three balls, and shot Russell in the forehead, he expired without a groan, I took out my knife and cut off about seven or eight pounds of flesh from the thick parts of his thighs. I made a fire and broiled some of it on the fire, and Jeffries and I ate about a pound of it, I put the rest into my knapsack, and Jeffries and I travelled on. (Manuscript 3251 1826, National Library of Australia).

The men were later asked about the rest of Russell's remains, and Jeffries described how a few days after killing their companion they had slaughtered a sheep and cut steaks from the man to fry up with the illicit mutton (Colonial Times and Tasmanian Advertiser 27 January $1826,3)$.

Jeffries and his notorious gang murdered at least eight people over a three-week period. The self-styled captain was finally apprehended after firing on a party sent out to capture him. Typical of its times, this party comprised two soldiers, a stockman, and three volunteers (one of whom was a convict), accompanied by an Aboriginal guide. An unnamed correspondent to one of the local newspapers wrote how as Jeffries was brought into Launceston on a cart 'it is quite impossible for me to express in adequate terms, or to do common justice to the feelings that were shewn by all descriptions of people, on the approach of the monster to the town'. The writer claimed that Launceston 'was literally glutted [sic] of its inhabitants; there must have been upwards of 500 persons crowding around the cart ... Their shouting reached the remotest parts of town' as the townsfolk threatened violence to the prisoner. Jeffries, who was later hanged, apparently confessed to all of his crimes, stating that the only act for which he was sorry was the murder of the infant Tibbs (Colonial Times and Tasmanian Advertiser 27 January 1826, 3). 
After having been found guilty of the murder of the Tibbs child, Jeffries was hanged at Hobart Town Gaol on the morning of 4 May 1826 alongside his erstwhile companion Perry and three other men, including bushranger Matthew Brady (Colonial Times and Tasmanian Advertiser 5 May 1826, 3).

\section{Conclusion}

The parallels between The Nightingale and the actual historical events that impacted on the lives of Elizabeth Tibbs, her husband, and child in mid-1820s Van Diemen's Land are uncanny, but also demand an appreciation of the film's historical veracity. The fictional Clare and historical Elizabeth were both gang-raped, saw their husbands shot dead, and had their infants murdered. In both instances the perpetrators then went on to commit other heinous acts including the abduction, rape, and murder of an Aboriginal woman, acts that went unpunished. This was Van Diemen's Land, replete with much colonial misery. Utilising the Tibbs case to offer a mimetic reading of the film highlights the lived realities of the island's colonial past, justifying the level of on-screen violence as being warranted as it reflects accurately historical events recorded as having taken place in the colony.

Even the minor divergences are telling, revealing a broader historical reality. In the historic case of Elizabeth Tibbs, those who offended against her and her family were white men who, as bushrangers, had put themselves outside of the law. Like Aboriginal people, bushrangers were considered to be a threat to the colony of Van Diemen's Land and were hunted, captured, then imprisoned or killed. As a free settler, Tibbs belonged to a higher social class than the fictional convict Clare. She therefore had recourse to the law of the land in pressing her case although, notably, Jeffries and Perry were charged with the murder of the infant Tibbs rather than with any crimes against Elizabeth's person. Their execution was judicially sanctioned, unlike the revenge killings of Hawkins and Ruse in which Clare was intimately involved. Bushrangers, while prevalent in 1820s Van Diemen's Land, were curiously absent from The Nightingale, perhaps because their presence would have muddied the waters when it came to depicting state-sanctioned violence enacted by the soldiery against those at the margins of colonial society.

While in the historical case study outlined above the perpetrators were bushrangers, the rapists and murderers depicted in The Nightingale were soldiers. This is significant as the on-screen violence of the soldiery speaks to a broader historical colonial violence. The redcoats function not only symbolically but also actually as the embodiment of the sovereign's power, authority, and will in Van Diemen's Land. In the film, the redcoats are emblematic of state-sponsored violence against marginalised groups (Irish convicts and 
Aboriginal people). The convict Clare has no realistic recourse to the law in pursuing justice following rape and murder at military hands. Even the body of her deceased baby fails to move the local magistrate who will not accept the word of an Irish convict woman over that of a redcoat. Clare is therefore left to enact her own revenge, ultimately with considerable assistance from Billy/Mangana, an Aboriginal man had also suffered at the hands of the British invaders.

Viewing realistic representations of violence against the person as enacted in the past with our current sensibilities in our \#MeToo age can be confronting. Had those who walked out of The Nightingale remained in their seats beyond the opening scenes depicting the unrelenting rape of a female convict and the murders of her husband and baby, they would have been exposed to scenes of extreme violence against Aboriginal people (rape, several murders, the chaining of prisoners by the neck, and the severing of an Aboriginal man's head). There is, as Rosenstone $(2018,25)$ has explained, 'not a single historical truth', but 'the factual truth, the narrative truth, the emotional truth, the psychological truth, [and] the symbolic truth'. Through recourse to the historical record, I have demonstrated that the violent encounters depicted in The Nightingale accurately reflect elements of Tasmania's lived reality in the years when the former colony was known as Van Diemen's Land where, at times, the depravity of historic actors even exceeded the heinous acts represented in the film. I argue that The Nightingale's narrative not only speaks to the factual truth of life in colonial Van Diemen's Land, but also engages with the emotional, psychological, and symbolic truths of life in an oppressive penal colony under autocratic rule, within which race, class, and gender determined not only who transgressed and who was punished, but also dictated who lived and died.

\section{Notes}

1. Bushrangers were predominantly male and were usually convicts who had absconded into the bush to live outside of colonial law. Some colonial officials also deserted their posts, took to the bush, and became bushrangers.

2. Elizabeth Grant and I have written about the extensive use of neck chains to restrain Aboriginal prisoners, a practice that was demonstrably used in Van Diemen's Land. Numerous Aboriginal people's corpses were mutilated following their murders or deaths. Well known instances of the heads of deceased peoples being severed include Yagan in Western Australia and Cannabygal in New South Wales. The Conciliator of Aborigines in Tasmania, George Augustus Robinson, is known to have robbed the graves of numerous deceased Tasmanian Aboriginal people while he 
had oversight of them at Wybalenna on Flinders Island, while in Hobart colonial surgeons mutilated Tasmanian Aboriginal remains, most notably those of William Lanne (see, in particular, Petrow 1997).

\section{References}

Boyce, James. 2008. Van Diemen's Land. Melbourne: Black Inc.

Brodie, Nick. 2017. The Vandemonian War: The Secret History of Britain's Tasmanian Invasion. Melbourne: Hardie Grant Books.

Collins, Felicity. 2008. "Historical Fiction and the Allegorical Truth of Colonial Violence in The Proposition." Cultural Studies Review 14 (1): 55-71.

Connor, John. 2002. The Australian Frontier Wars 1788-1838. Sydney: UNSW Press.

Dalziell, Tanya. 2009. "Gunpowder and Gardens: Reading Women in The Proposition." Studies in Australasian Cinema 3(1): 121-131.

Daniels, Kay. 1998. Convict Women. Sydney: Allen \& Unwin.

Harman, Kristyn. 2012. Aboriginal Convicts: Australian, Khoisan, and Māori Exiles. Sydney: UNSW Press.

Harman, Kristyn. 2009. “'Send in the Sydney Natives!”: Deploying Mainlanders Against Tasmanian Aborigines.” Tasmanian Historical Studies 14: 5-24.

Harman, Kristyn and Elizabeth Grant. 2014. "'Impossible to Detain Without Chains?': The Use of Restraints on Aboriginal People in Policing and Prisons." History Australia 11(3): 157-176.

Hughes-Warrington, Marnie. 2007. History Goes to the Movies. Oxon: Routledge.

Johnson, Murray and Ian McFarlane. 2015. Van Diemen's Land: An Aboriginal History. Sydney: New South Publishing.

Mendes, Kaitlynn, Ringrose, Jessica and Jessalynn Keller. 2018. "\#MeToo and the Promise and Pitfalls of Challenging Rape Culture Through Digital Feminist Activism." European Journal of Women's Studies 25(2): 236-246.

Petrow, Stefan. 1997. "The Last Man: The Mutilation of William Lanne in 1869 and its Aftermath." Aboriginal History 21: 90-112.

Perry, John. 1826. “The Voluntary Statement of John Perry.” Manuscript 3251, Box 2, Volume 2. Canberra: National Library of Australia.

Rosenstone, Robert. 2018. History on Film/Film on History (third edition). London: Routledge.

Thomas, Sarah. 2019. "Sydney Film Festival Controversy as Audiences Walk Out of The Nightingale" ABC News, (updated) 19 July.

Unattributed, Colonial Times and Tasmanian Advertiser, 13 January 1826, 4.

Unattributed, Colonial Times and Tasmanian Advertiser, 27 January 21826, 3. 
15

Unattributed, Colonial Times and Tasmanian Advertiser, 5 May 1826, 3. Unattributed, Hobart Town Gazette, 29 April 1826, 2. 